\title{
A novel first exon directs hormone- sensitive transcription of the pig prolactin receptor
}

\author{
Anke Schennink, Josephine F Trott, Bradley A Freking ${ }^{1}$ and Russell C Hovey \\ Department of Animal Science, University of California Davis, 2335 Meyer Hall, One Shields Avenue, Davis, \\ California 95616, USA \\ 'USDA, ARS, US Meat Animal Research Center, PO Box 166, Clay Center, Nebraska 68933, USA
}

Correspondence should be addressed to A Schennink

Email

aschennink@ucdavis.edu

\begin{abstract}
Endocrine, paracrine, and autocrine prolactin (PRL) acts through its receptor (PRLR) to confer a wide range of biological functions, including its established role during lactation. We have identified a novel first exon of the porcine PRLR that gives rise to three different mRNA transcripts. Transcription of this first exon is tissue specific, where it increases during gestation in the adrenal glands and uterus. Within the mammary glands, its transcription is induced by estrogen and PRL, while in the uterus, its expression is downregulated by progestin. The promoter region has an enhancer element located between -453 and -424 bp and a putative repressor element between -648 and $-596 \mathrm{bp}$. Estrogen, acting through the estrogen receptor, activates transcription from this promoter through both E-box and transcription factor AP-2 $\alpha$ binding sites. These findings support the concept that the multilevel hormonal regulation of PRLR transcription contributes to the various biological functions of PRL.
\end{abstract}

Key Words

- promoter

- prolactin receptor

- alternative splicing

- pig
Journal of Molecular Endocrinology (2013) 51, 1-13

\section{Introduction}

Prolactin (PRL) is a protein hormone that has diverse biological functions including pronounced roles in adaptive stress responses, osmoregulation, uterine function, proliferation and differentiation of the mammary glands, and lactation (Bole-Feysot et al. 1998). PRL functions through multiple forms of its membrane-associated receptor (PRLR) that differ primarily within the intracellular domain as described for human, mouse, rat, cow, pig, sheep, goat, and carp. Upon ligand activation, these various isoforms can differentially activate downstream signal transduction pathways (reviewed in Trott et al. (2012)). The PRLR is expressed in various tissues and cell types, where its levels vary during states including the estrus cycle, pregnancy, and lactation (Jahn et al. 1991, Hovey et al. 2001, Trott et al. 2009). The PRLR is also expressed in a majority of human breast cancers (Gill et al. 2001, Peirce \& Chen 2001), where antagonism of the PRLR potentiates the cytotoxic action of anti-cancer drugs and reduces PRL-induced cell survival (Howell et al. 2008).

Expression of the PRLR across various tissues and physiological states is under complex transcriptional regulation. Six alternative non-coding first exons have been reported in humans, including a generic exon 1 $\left(\mathrm{hE} 1_{3}\right)$ that is orthologous to $\mathrm{E} 1_{3}$ in rat and mouse $(\mathrm{Hu}$ et al. 1999, 2002). The $\mathrm{E} 1_{3}$ is expressed in the mammary glands, ovaries, Leydig cells, and liver of both humans and rats (Moldrup et al. 1996, Hu et al. 1999). In addition to $\mathrm{E}_{3}$, four other gonad-, liver-, and brain-specific first exons have been identified in rats (Hu et al. 1996, Moldrup et al. 1996, Hu et al. 1997, Tanaka et al. 2002, 2005) and mice

Published by Bioscientifica Ltd 
(Ormandy et al. 1998, Tabata et al. 2012). Transcription from these alternative first exons is controlled by upstream promoters that recruit specific cis-acting factors. In turn, activation of these promoters could lead to differential expression of the PRLR across tissues, thereby contributing to the diverse biological functions of PRL.

Apart from data for humans, rats, and mice, no literature is available on the $5^{\prime}$ UTR of the PRLR or its regulation in livestock where reproduction and lactation underlie a multi-billion dollar industry. At the same time, production animals are increasingly important as biomedical models for cancer, obesity, and infertility (Kuzmuk \& Schook 2011). Furthermore, expression of the first exons of the PRLR across a broad array of tissues has not been analyzed in any species, nor has its hormonal control been investigated for established PRL target tissues such as the mammary glands or uterus in vivo.

In this study, we identified multiple splice variants of a porcine PRLR E1 (pE1). We investigated the expression of three pE1 splice variants across various tissues in virgin and pregnant females and found that expression levels increased during pregnancy in the adrenal glands and endometrium. Expression analysis in a 'hormone-replacement' model in vivo established that pE1 was positively regulated by $\beta$-estradiol (E) and PRL in the mammary glands and negatively regulated by progestin in the uterus. Furthermore, E activated the pE1 promoter in E-responsive breast cancer cells through E-box and transcription factor AP- $2 \alpha$ (TFAP2A) binding sites.

\section{Materials and methods}

\section{Animals}

Virgin and pregnant (day 105 of gestation) crossbred (Hampshire $\times$ Yorkshire) gilts and boars were housed, treated, killed, and their tissues sampled as described (Trott et al. 2011). Tissues from pregnant (day 105 of gestation) gilts, and testis from a boar, were used for $5^{\prime}$ RACE. Tissues from virgin gilts were used to determine tissue-specific expression in non-pregnant animals. Pregnant, unilaterally hysterectomized-ovariectomized gilts were killed at day $25,45,65,85$, or 105 of gestation and were housed, treated, and sampled as described (Freking et al. 2007).

Hormone-treated peripubertal Yucatan miniature pigs were housed, treated, killed, and their tissues harvested as described (Horigan et al. 2009). A total of 36 gilts were used, of which four were sham-operated, while 32 were ovariectomized. One day after surgery, ovariectomized gilts began receiving bromocriptine $(\mathrm{Br} ; 0.1 \mathrm{mg} / \mathrm{kg}$ per day i.m.) for 8 days to suppress PRL secretion. Beginning on day 9 , gilts were injected i.m. with various combinations of $\mathrm{E}(0.1 \mathrm{mg} / \mathrm{kg}$ per day), medroxyprogesterone 17 -acetate (a synthetic progestin (P), $0.25 \mathrm{mg} / \mathrm{kg}$ per day), and/or $\mathrm{Br}$ or haloperidol (Hal; $1.5 \mathrm{mg} / \mathrm{kg}$ per day; to induce endogenous PRL release) for 5 days. The ovariectomized, Br-treated gilts were assigned to one of the eight treatments ( $n=4$ per group): $\mathrm{Br}, \mathrm{Br}+\mathrm{E}, \mathrm{Br}+\mathrm{P}, \mathrm{Br}+\mathrm{E}+\mathrm{P}$, $\mathrm{Hal}, \mathrm{Hal}+\mathrm{E}, \mathrm{Hal}+\mathrm{P}$, and $\mathrm{Hal}+\mathrm{E}+\mathrm{P}$. Sham-ovariectomized gilts received daily injections of saline for 14 days. All gilts were killed 14 days after surgery.

\section{$5^{\prime}$ RACE}

Poly A+RNA (Oligotex mRNA Mini Kit, Qiagen) was isolated from mammary gland, placenta, liver, kidney, adrenal, ovary, and testis, and $5^{\prime}$ RACE was performed using the SMARTer RACE cDNA amplification kit (Clontech) with two gene-specific primers: GSP1a, 5'-CGGAGGTGACTGTCCATTCAGAAGGCTG-3' and NGSP1a， 5'-TTGGCTCCCTTCTCTTTCCACAGGCAG-3' (designed from the $P P R L R$ cDNA, GenBank ID: NM_001001868) or the $5^{\prime} / 3^{\prime}$ RACE Kit (Roche) with primers reported in Trott et al. (2007) using two rounds of nested PCR. $5^{\prime}$ RACE products from the nested PCR were identified by electrophoresis on $1.2 \%$ agarose gels, gelpurified, and cloned into pCR2.1-TOPO (Invitrogen). Clones were analyzed by restriction enzyme digestion and agarose gel electrophoresis before sequencing. The sequence of the PPRLR first exon was confirmed by sequencing a bacterial artificial chromosome (BAC) containing the pPRLR (CHORI-242 255C20, a gift from Dan Nonneman, USDA-ARS) using a sequencing primer in the newly discovered $\mathrm{pE} 1$.

\section{RNA extraction and RT}

Tissues were homogenized in TriReagent (Molecular Research Center, Inc., Cincinnati, OH, USA) and total RNA was extracted according to the manufacturer's instructions. Total RNA $(5 \mu \mathrm{g})$ was treated with DNaseI (Roche) and purified using the DNA-Free RNA Kit (Zymo Research Corporation, Orange, CA, USA) before confirmation of its integrity by formaldehyde-agarose gel electrophoresis. Total RNA (500 ng) was denatured at $70{ }^{\circ} \mathrm{C}$ for $5 \mathrm{~min}$ along with oligo-dT (50 ng, Amersham Biosciences) and random hexamers (2 ng, Amersham Biosciences) and then reverse transcribed using $1 \times \mathrm{RT}$

Published by Bioscientifica Ltd. 
Table 1 Primers used for PCR amplification of $p P R L R$ E1 promoter fragments cloned into PCR2.1

\begin{tabular}{l}
\hline Oligo \\
\hline pPRLRE1_F170 \\
pPRLRE1_F424 \\
pPRLRE1_F651 \\
pPRLRE1_F859 \\
pPRLRE1_F1002 \\
pPRLRE1_F1176 \\
pPRLRE1_R
\end{tabular}

Primer sequence $\left(5^{\prime}-3^{\prime}\right)$

CCAGCCAGGAACAGAAATGT CTTGGCTGCCAGGAGAAATA CCTGGAAGTTTGGGTTTTGA TGGTGGTTGTGTGTGGTTTT CCCTCTGGGTTATGAAACGA AGTGTCCTGGGATACGCAGT CTGCAAAAGGACGTGGAGAT

Buffer (Promega), dNTP mixture (0.016 mM, Promega), Moloney's murine leukemia virus reverse transcriptase ( $2 \mathrm{U} / \mu \mathrm{l}$, Promega), and RNase inhibitor $(0.85 \mathrm{U} / \mu \mathrm{l}$, Promega) at $37^{\circ} \mathrm{C}$ for $90 \mathrm{~min}$, followed by denaturation at $95{ }^{\circ} \mathrm{C}$ for $5 \mathrm{~min}$.

\section{Cloning pE1 transcripts}

Mammary gland cDNA was amplified with GoTaq Green Master Mix (Promega) using $0.2 \mu \mathrm{M}$ each of the primers pE1_F, 5'-GACTGATACTGCAGACTGACTTTGCT-3' and pE3/4_R, 5'-GGAGGTGACTGTCCATTCAGA-3' (spanning exons 3 and 4 ) to confirm the existence of splice variants involving the first three exons of the pPRLR. Differentsized PCR products were agarose gel-purified, cloned into pCR2.1-TOPO, and sequenced.

\section{Quantitative PCR}

The cDNA was diluted 1:1, and $4 \mu \mathrm{l}$ was used as a template for real-time quantitative PCR (qPCR) containing Fast SYBR Green Master Mix (Applied Biosystems) and $0.2 \mu \mathrm{M}$ of each primer on a 7500 Fast Real-Time PCR System (Applied Biosystems), using primers named for the exons in which they are located: pE1/3_F, 5'-CCGGCAAAATGAACCTCTGA-3' and pE3_R, 5'-TGTGGATGGCACATTTTCCTT-3'; pE1_F, 5'-GACTGATACTGCAGACTGACTTTGCT-3' and pE2/3_R, 5'-GGTCAGAGGTTCACTTCAGGGGTCAT-3'; pE1_F, 5'-GACTGATACTGCAGACTGACTTTGCT-3' and pE2/2.1_R, 5'-GGATGGGAGCCTTCAGGG-3', for transcripts $\mathrm{pE} 1 / 3, \mathrm{pE} 1 / 2 / 3$, and $\mathrm{pE} 1 / 2 / 2.1 / 3$ respectively. Samples were analyzed as duplicates. A standard curve with a range from 10 to $10^{7}$ copies was prepared for each $P P R L R$ transcript using mouse liver cDNA spiked with the respective number of copies of PPRLR cDNA cloned into pCR2.1-TOPO. The standard curve was spiked into mouse cDNA to ensure that the standard curve and samples had a similar composition.
The same standard curve was used in duplicate or triplicate across multiple plates for each transcript. Standard curves were generated by linear regression of $C t$ vs $\log _{10}$ (dilution factor). Melting curve analysis was used to confirm the specificity of PCR products, and a minus-RT control was used to ensure that products were from cDNA rather than genomic DNA. Gene expression levels were normalized for $18 S$ rRNA expression (Trott et al. 2011).

\section{Construction of promoter plasmids}

A 1171-nucleotide promoter sequence was obtained by sequencing BAC CHORI-242 255C20 using a reverse primer in pE1 and primer walking upstream. Promoter fragments of various lengths were generated by PCR from this BAC by one of the two methods. First, fragments were generated using primers listed in Table 1 and Extensor PCR mix (ABgene, Epsom, UK) followed by subcloning into pCR2.1-TOPO. Promoter fragments were then excised and ligated into the promoterless pGL3-Basic vector (Promega) using the Quick Ligation Kit (New England BioLabs, Ipswich, MA, USA). Further deletions of the $\mathrm{pE} 1$ promoter were generated by PCR using primers listed in Table 2 and GoTaq Green Mastermix (Promega). These fragments were ligated into pGL3-basic using the In-Fusion PCR Cloning system (Clontech). Mutations in the TFAP2A and E-box binding sites of the 201 and $242 \mathrm{bp}$ pE1 promoter fragments were generated from pGL3-pPRLR E1_1176 by PCR using primers listed in Table 3. PCR was performed using GoTaq Green Mastermix (Promega) and products were ligated into pGL3-basic using the Gibson Assembly

Table 2 Primers used for PCR amplification of $p P R L R$ E1 promoter fragments cloned using the In-Fusion PCR cloning system

\begin{tabular}{|c|c|}
\hline Oligo & Primer sequence $\left(5^{\prime}-3^{\prime}\right)$ \\
\hline pPRLRE1_201F & $\begin{array}{l}\text { TATCGATAGGTACCGTTGCAGGCTGAAG- } \\
\text { AAAATCA }\end{array}$ \\
\hline pPRLRE1_242F & $\begin{array}{l}\text { TATCGATAGGTACCGCTCCCTCCCTCACCT- } \\
\text { GGTA }\end{array}$ \\
\hline pPRLRE1_293F & $\begin{array}{l}\text { TATCGATAGGTACCGGGGAATCCGTGCTC- } \\
\text { TCTTCT }\end{array}$ \\
\hline pPRLRE1_353F & $\begin{array}{l}\text { TATCGATAGGTACCGCTTTTCTGGTGCAG- } \\
\text { TCTCAGC }\end{array}$ \\
\hline pPRLRE1_453F & $\begin{array}{l}\text { TATCGATAGGTACCGAGGAAATTTGACA- } \\
\text { CGGAGACA }\end{array}$ \\
\hline pPRLRE1_500F & $\begin{array}{l}\text { TATCGATAGGTACCGCCCCAAGGCTGTCA- } \\
\text { AGATAC }\end{array}$ \\
\hline pPRLRE1_567F & $\begin{array}{l}\text { TATCGATAGGTACCGCTGTCGCCCCTTTC- } \\
\text { ACTCT }\end{array}$ \\
\hline pPRLRE1_596F & $\begin{array}{l}\text { TATCGATAGGTACCGCTCAGGTCACAGG- } \\
\text { GGTCACT }\end{array}$ \\
\hline pPRLRE1_infR & $\begin{array}{l}\text { TCGAGCCCGGGCTAGCTGCAAAAGGAC- } \\
\text { GTGGAGAT }\end{array}$ \\
\hline
\end{tabular}

Published by Bioscientifica Ltd. 
Table 3 Primers used for PCR amplification of mutant transcription factor binding sites in the $P P R L R$ E1 promoter, cloned using the Gibson Assembly cloning kit. Altered nucleotides are lower case. The E-box (242 bp promoter) and TFAP2A (201 bp promoter) sites are underlined

\begin{tabular}{|c|c|}
\hline Oligo & Primer sequence $\left(5^{\prime}-3^{\prime}\right)$ \\
\hline pPRLRE1_201mut & $\begin{array}{l}\text { CGATAGGTACCGAGCTTTGCAGGCTGAAGA- } \\
\text { AAATCACTGTTTTaatTCC }\end{array}$ \\
\hline pPRLRE1_242mut & $\begin{array}{l}\text { CGATAGGTACCGAGCTCTCCCTCCCTtgtCTG- } \\
\text { GTAAAAC }\end{array}$ \\
\hline pPRLRE1_gibR & $\begin{array}{l}\text { AGATCTCGAGCCCGGGCTGCAAAAGGACGT- } \\
\text { GGAGAT }\end{array}$ \\
\hline
\end{tabular}

cloning kit (New England BioLabs). All promoter fragments were sequence-verified.

\section{Transient transfection of MCF-7 cells and reporter gene assays}

Human MCF-7 breast cancer cells were cultured in DMEM supplemented with 10\% FBS, $100 \mathrm{U}$ penicillin and $100 \mu \mathrm{g}$ streptomycin/ml, and $2.42 \mathrm{~g} / \mathrm{l}$ HEPES. Cells were plated into 12 -well plates at $2 \times 10^{5}$ cells/well, then 1 day later were transiently transfected with $0.8 \mu \mathrm{g}$ of either $\mathrm{pE} 1$ promoter-pGL3 plasmid or pGL3-basic DNA and $0.2 \mu \mathrm{g}$ of either pEF-lacZ or pCMV-eGFP plasmid using $3 \mu$ FuGene6 (Roche). In some studies, cells were transfected with $0.4 \mu \mathrm{g}$ of either pE1 promoter-pGL3 plasmid or pGL3-basic plasmid and $0.1 \mu \mathrm{g}$ of pCMV-eGFP, using $1.5 \mu$ l Lipofectamine LTX and $0.5 \mu$ l PLUS (Invitrogen). In the promoter deletion experiment, cells were cultured in complete growth medium and harvested after $24 \mathrm{~h}$. In experiments examining induction of the $\mathrm{pE} 1$ promoter by $\mathrm{E}$, the culture medium was changed to hormone-deficient medium (containing 10\% charcoal-stripped FBS; Omega Scientific, Tarzana, CA, USA) the day after transfection. Cells were then exposed to $\mathrm{E}(1 \mathrm{nM})$ or ethanol vehicle for $48 \mathrm{~h}$. In the experiment using the estrogen receptor (ESR) antagonist ICI 182780 (ICI; Ascent Scientific, Cambridge, MA, USA; $100 \mathrm{nM}$ in ethanol), the culture medium was changed to hormone-deficient medium the day after transfection. Cells were then exposed to either ICI (100 nM) or vehicle for $24 \mathrm{~h}$ before treatment with either E, E+ICI, or vehicle for $48 \mathrm{~h}$ in hormone-deficient medium. Cells were lysed with $200 \mu \mathrm{l}$ Glo Lysis buffer (Promega) and lysates were assayed for luciferase and either $\beta$-galactosidase or eGFP activity. Luciferase activities were corrected for transfection efficiency as determined by the relative level of $\beta$-galactosidase or fluorescence in each lysate.

\section{Transcription factor binding sites}

Putative binding sites for transcription factors in the pE1 promoter sequence were identified using TESS (http:// www.cbil.upenn.edu/cgi-bin/tess/tess) and AliBaba 2.1 (http://www.gene-regulation.com/pub/programs/alibaba2/ index.html). For TESS, only sites with a Log-likelihood score $(\mathrm{La}) \geq 10$ were considered.

\section{Statistical analysis}

Data were analyzed using the General Linear Models procedure in SAS (SAS version 9.3, SAS Institute, Inc., Cary, NC, USA). Expression data were $\log _{10}$ or power transformed for normalization where appropriate. Expression data from virgin, hormone-treated gilts were analyzed within each tissue by ANOVA followed by Tukey's post hoc test. Main effects of hormones and their interaction were tested by factorial ANOVA. Expression data from pregnant gilts were analyzed within tissue by linear regression. Luciferase activity data from the promoter deletion and mutation studies were analyzed by ANOVA. Significance was declared at $P<0.05$.

\section{Results}

\section{Identification of a novel pPRLR first exon}

Using 5' RACE, we obtained 35 clones of 200-250 bp from reverse-transcribed RNA from mammary gland, liver, placenta, adrenal gland, kidney, ovary, and testis. All clones were identified as spanning from a novel exon 1 (pE1) to exon 3 of the $P P R L R$, where $54 \%$ of the clones also contained a 62 bp non-coding exon 2. One clone contained 162 bp of pE1, as confirmed by its alignment with genomic sequence. The $162 \mathrm{bp}$ of $\mathrm{pE} 1$ is located more than $91 \mathrm{~kb}$ upstream of exon 2 on Sus scrofa chromosome 16 (SSC16; Fig. 1A). Among the clones, 23\% had a transcription start site $23 \mathrm{bp}$ downstream that conferred a length of $139 \mathrm{bp}$ for $\mathrm{pE} 1$, while $15 \%$ of clones had a transcription start 59 bp downstream that conferred a pE1 length of 80 bp. Using RT-PCR, we further identified three distinct splice variants involving exon $\mathrm{pE} 1$. Two were identical to our 5' RACE products, namely $\mathrm{pE} 1 / 3$ and $\mathrm{pE} 1 / 2 / 3$. The largest PCR product contained a novel exon of $113 \mathrm{bp}$ that is located between exons 2 and 3 , which was designated as non-coding exon 2.1 (Fig. 1A), giving rise to the transcript pE1/2/2.1/3. A multiple sequence alignment revealed that $\mathrm{pE} 1$ is homologous to the generic $\mathrm{E} 1_{3}$ in humans, rats, and mice (Fig. 1B).

Published by Bioscientifica Ltd 


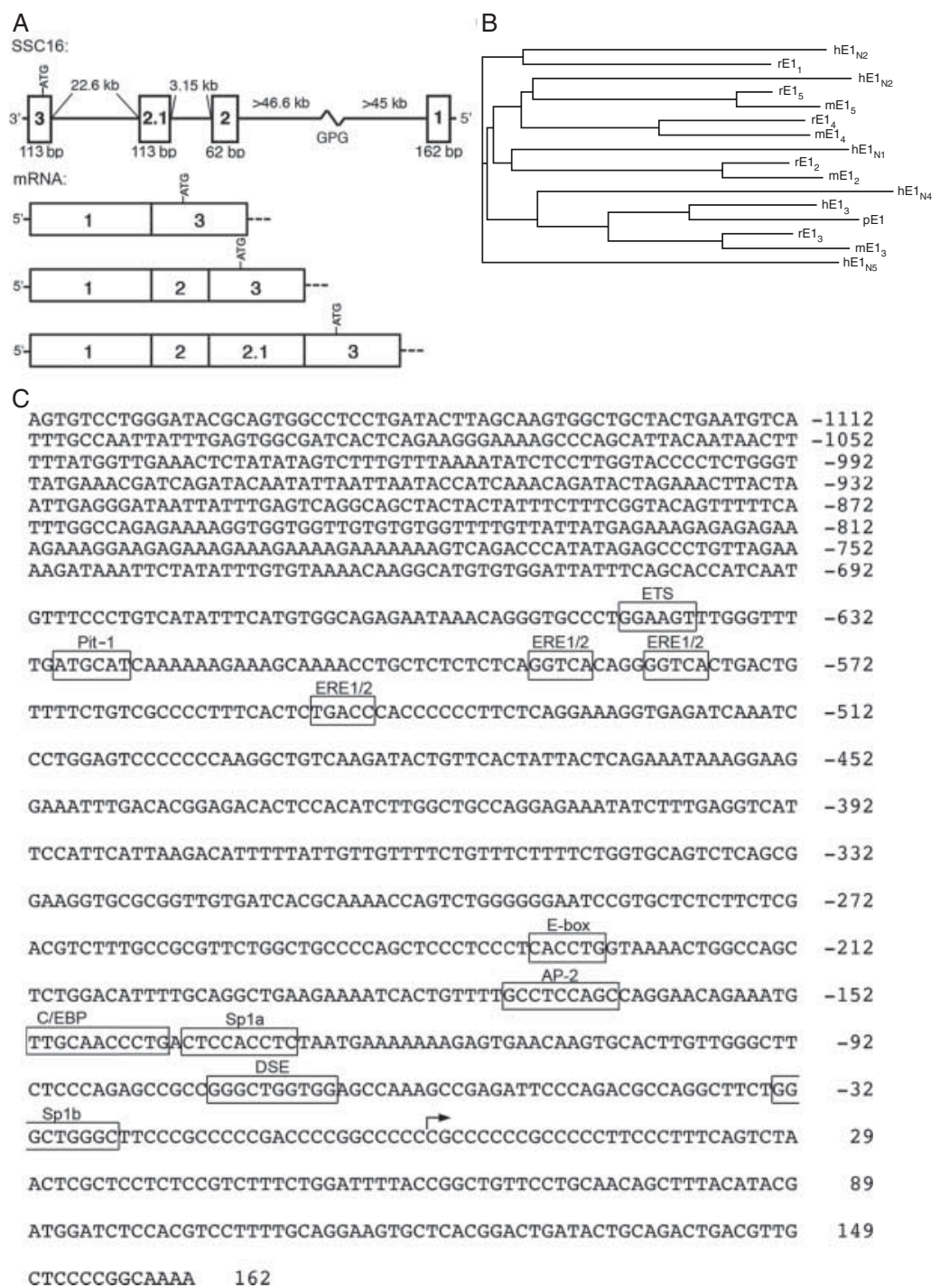

Figure 1

Identification of the $5^{\prime}$ UTR and promoter region of $p P R L R$. (A) Top panel, genomic structure of exons 1, 2, 2.1, and 3 of the PPRLR on Sus scrofa chromosome 16 (SSC16; according to Sus scrofa build 10.2, Ensembl release 67). The translation initiation site is located in exon 3. GPG, Golden Path Gap. Bottom panel, the three newly identified pPRLR splice variants. All transcripts starting with exon 1 are spliced onto exon 3 , with or without the non-coding exon 2. Transcripts that splice onto exon 2.1 always included exon 2 (GenBank ID: JX429229). (B) Cladogram generated from all six human E1

\section{Tissue-specific expression of pPRLR E1 in virgin and pregnant gilts}

Expression of these three pE1 transcripts in a wide range of tissues from virgin gilts was determined by qPCR. The $\mathrm{pE} 1 / 3$ and $\mathrm{pE} 1 / 2 / 3$ transcripts $\left(>10^{5}\right.$ copies/ $\mu \mathrm{g}$ RNA) were most abundant in the adrenal glands, endometrium, mammary glands, pituitary, and placenta (Fig. 2A and B), while the $\mathrm{pE} 1 / 2 / 2.1 / 3$ transcript was most abundant in the
(hE1), five rat $E 1$ ( $r E 1)$, and four murine $E 1$ ( $m E 1)$, and $\mathrm{pE1}$, showing that the $\mathrm{pE} 1$ is homologous to $\mathrm{hE1} 1_{3}, \mathrm{rE1} 1_{3}$, and $\mathrm{mE} 1_{3}$. (C) Nucleotide sequence of the pE1 and its $5^{\prime}$ flanking region (GenBank ID: JX429230). Numbering is relative to the main transcription start site depicted by an arrow. Predicted transcription factor binding sites are boxed. ETS, E26 transformation specific; Pit-1, pituitary 1; ERE1/2, estrogen response element half-site; C/EBP, CCAAT/ enhancer binding protein; AP-2, transcription factor AP-2 $\alpha$; Sp1, specificity protein 1; DSE, downstream sequence element.

adrenal glands, heart, mammary glands, pituitary, and placenta (Fig. 2C). Very low or no expression of pE1 was detected in liver, lymph node, pancreas, skeletal muscle, and thymus. Notably, expression of the pE1/2/2.1/3 transcript was $\sim 100$-fold lower than that for the two other pE1 transcripts in all tissues.

Given the crucial role for PRL during gestation, we further examined expression of the pE1 transcripts in

Published by Bioscientifica Ltd. 
A

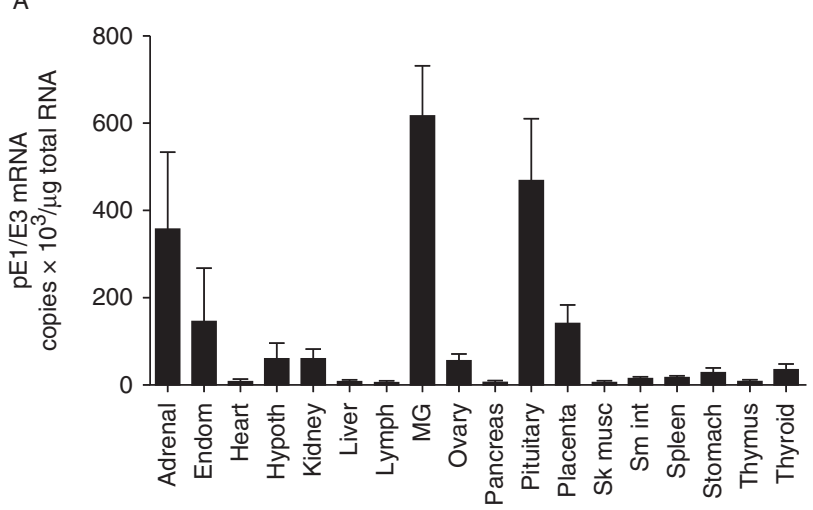

B

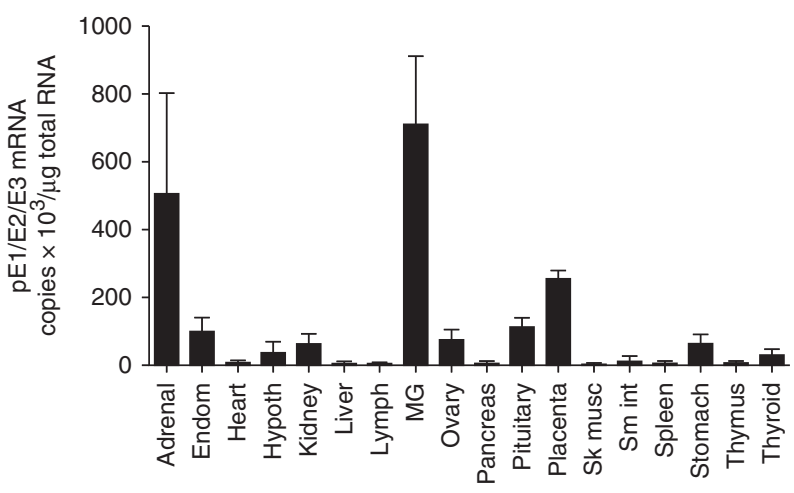

C

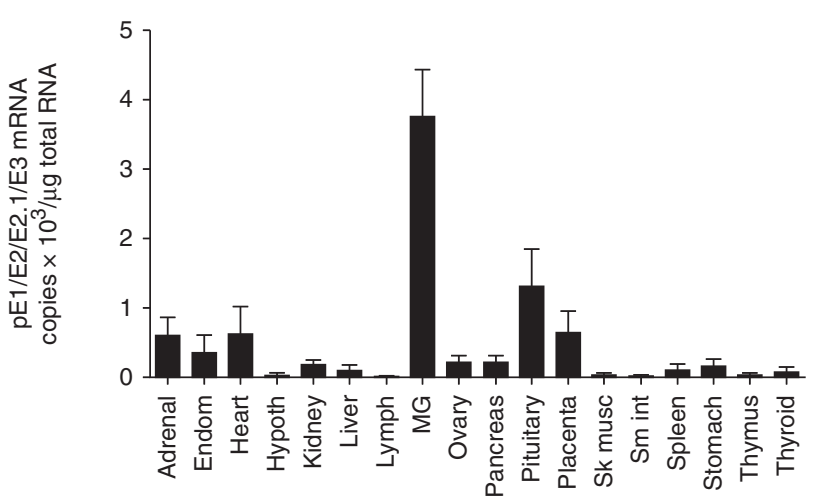

Figure 2

Expression of different $p P R L R$ exon 1 transcripts across various tissues in virgin gilts. Number of $p P R L R$ mRNA copies was measured by qPCR with normalization for the corresponding level of 185 rRNA. (A) Transcript $p E 1 / 3$, (B) transcript $p E 1 / 2 / 3$, (C) transcript $p E 1 / 2 / 2.1 / 3$. Endom, endometrium; Hypoth, hypothalamus; MG, mammary gland; Lymph, lymph node; Sk musc, skeletal muscle; Sm int, small intestine. Data are means \pm s.E.M. $(n=3)$.

various tissues from gilts at days $25,45,65,85$, and 105 of gestation (Fig. 3). The highest expression of pE1 was recorded in the adrenal glands, endometrium, and mammary glands, while it was barely detectable in the liver. Expression of all three pE1 transcripts in adrenal glands and endometrium increased linearly during gestation (Fig. 3). Expression of the pE1/3 and pE1/2/3 transcripts also increased linearly across gestation in the hypothalamus, as did expression of the pE1/3 transcript in the kidney, liver, mammary glands, and pituitary. These data reveal that pE1 expression is upregulated during gestation, particularly in known targets for PRL, leading us to hypothesize that pE1 is hormonally regulated.

\section{Hormonal regulation of $p P R L R$ E1}

Given our previous finding that expression of the long form of the pPRLR (pPRLR-LF) is regulated by PRL in the mammary glands, and by $\mathrm{E}$ and $\mathrm{P}$ in the uterus (Trott et al. 2009), alongside findings by others that $\mathrm{E}$ regulates $\mathrm{E} 1$ expression in rats and human breast cancer cells, we further examined the regulation of pE1 transcription by $\mathrm{E}$, $\mathrm{P}$, and PRL in the uterus, liver, and mammary glands in vivo (Fig. 4). The female pigs were hormone deficient before treatment with either $\mathrm{Br}$ (hypoprolactinemic) or Hal (hyperprolactinemic) in the presence or absence of $\mathrm{E}$ and/or $\mathrm{P}$. There was a negative main effect of $\mathrm{P}$ on the expression of all pE1 transcripts in the uterus $(P<0.0001)$. For the pE1/3 transcript, there was also a positive main effect of $\mathrm{E}(P<0.04)$ and a negative interaction between the effects of $\mathrm{E}$ and $\mathrm{P}(P=0.02)$, and PRL and $\mathrm{P}(P=0.05)$. For the liver, there was a small but significant negative main effect of $\mathrm{P}$ on the expression of all three transcripts $(P=0.01,0.01$, and 0.04 for $\mathrm{pE} 1 / 3, \mathrm{pE} 1 / 2 / 3$, and $\mathrm{pE} 1 / 2 / 2.1 / 3$ respectively), as well as a positive main effect of PRL on the expression of pE1/3 $(P=0.01)$ and $\mathrm{pE} 1 / 2 / 3$ $(P=0.002)$. Both $\mathrm{E}$ and $\mathrm{Hal}$ exerted positive main effects $(P<0.01)$ on expression of all three pE1 transcripts in the mammary glands, and there was an interaction between the effects of PRL and P $(P=0.01)$ for expression of the pE1/3 transcript.

\section{Analysis of the putative $P P R L R$ E1 promoter}

The $1.2 \mathrm{~kb}$ region upstream of $\mathrm{pE} 1$ was sequenced from BAC clone CHORI-242 255C20 (Fig. 1C). The promoter region is numbered from the transcription start site defined by the longest $5^{\prime}$ RACE transcript of pE1 (162 bp). We did not identify a TATA box within $40 \mathrm{bp}$ upstream of this, or the other two, potential transcription start sites. We used MCF-7 epithelial breast cancer cells, a widely used model for trans-species E-responsiveness in vitro, to study pE1 promoter activity. Deletion of the region -1171 to $-648 \mathrm{bp}$ of the pE1 promoter did not affect its transcriptional activity in transiently transfected MCF-7

Published by Bioscientifica Ltd 


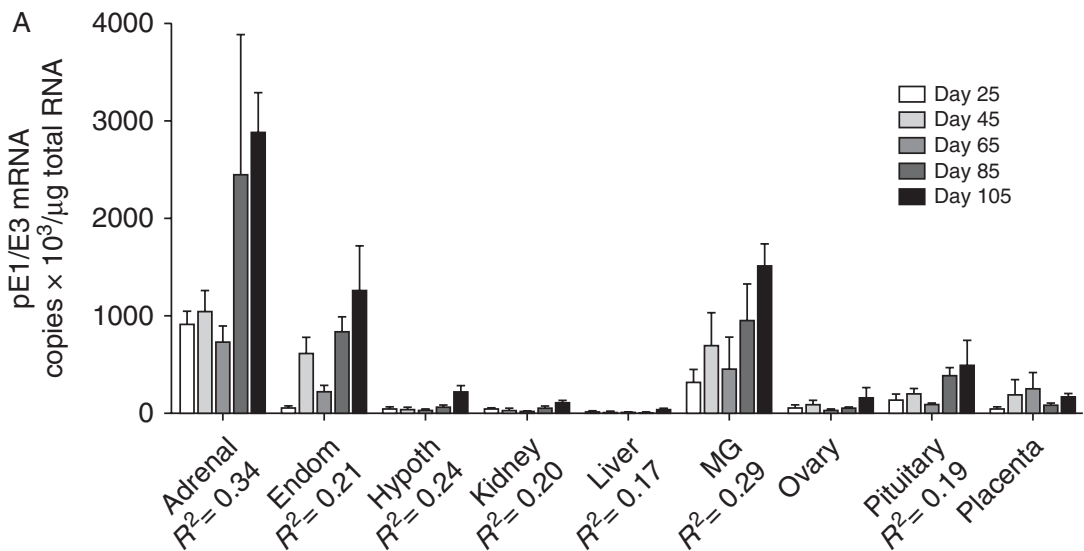

B

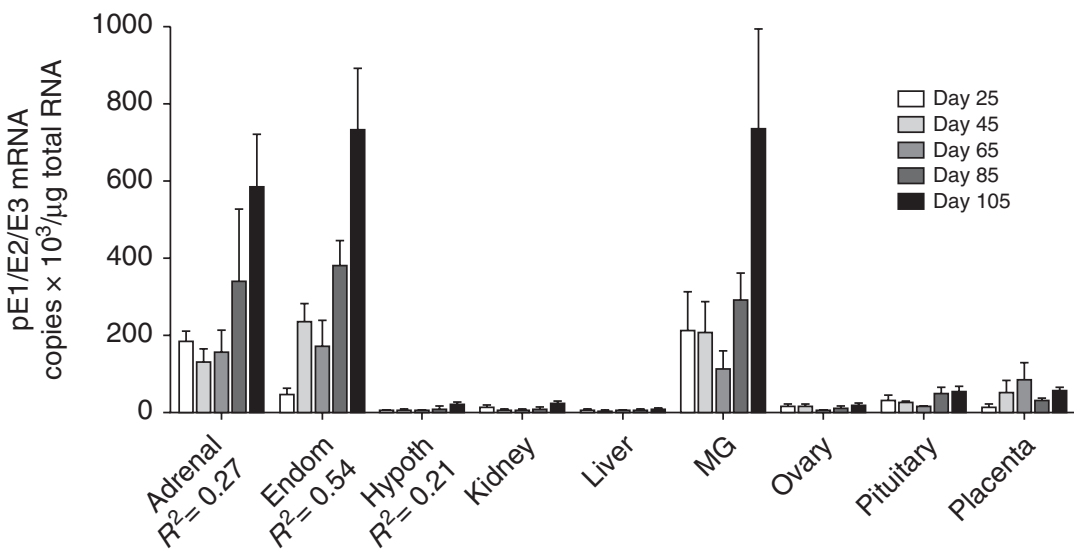

C

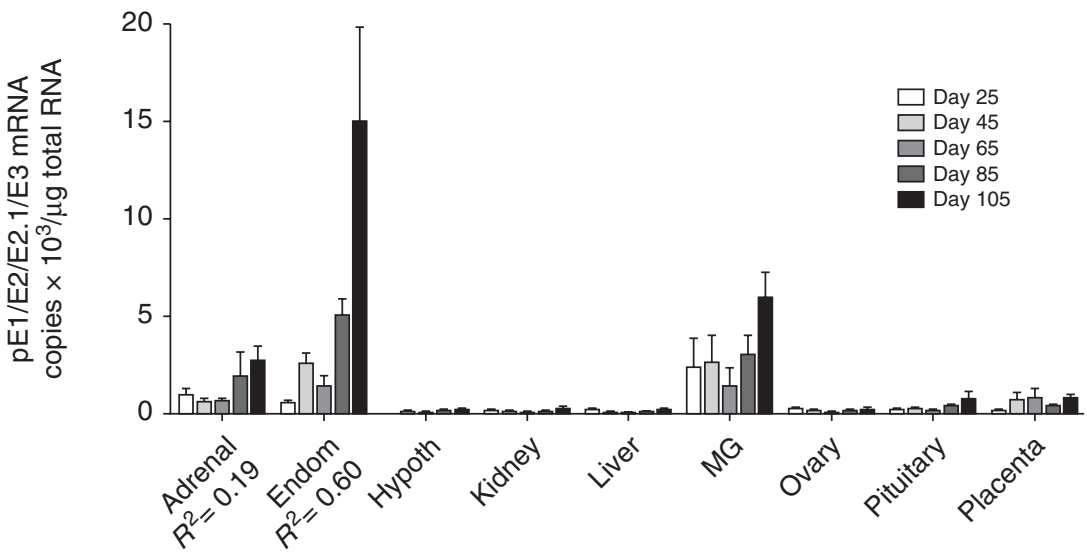

Figure 3

Expression of the different $p P R L R$ exon 1 transcripts across tissues from gilts at different stages of gestation. Copy number of total PPRLR mRNA was measured by qPCR with normalization for the corresponding level of 185 rRNA. (A) Transcript pE1/3. (B) Transcript pE1/2/3. (C) Transcript pE1/2/2.1/3.
Endom, endometrium; Hypoth, hypothalamus; MG, mammary gland Data are means \pm S.E.M. $(n=4-5)$. Where a significant linear relation existed between expression and time of gestation, the $R^{2}$ for the correlation is shown. 


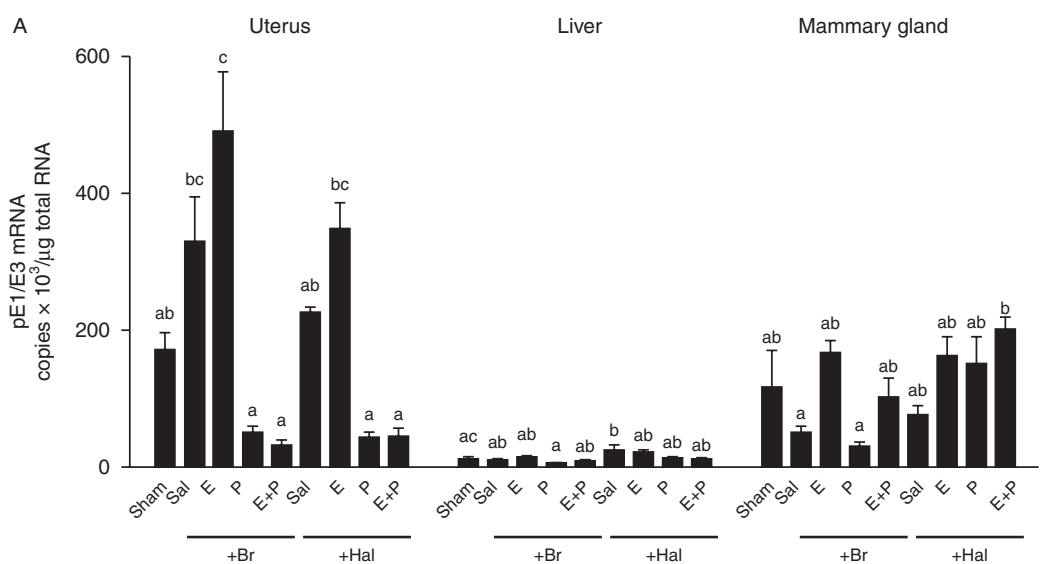

B

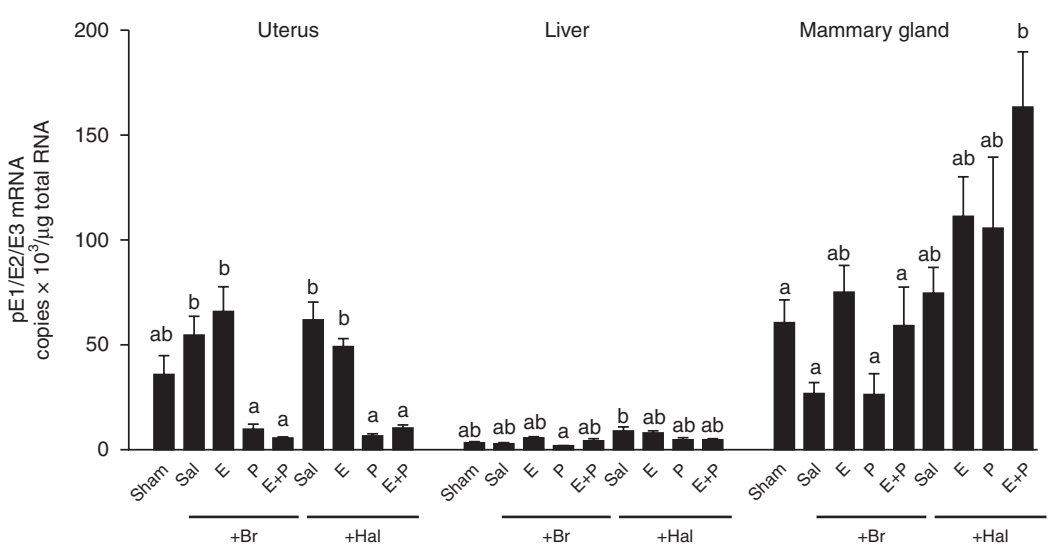

C

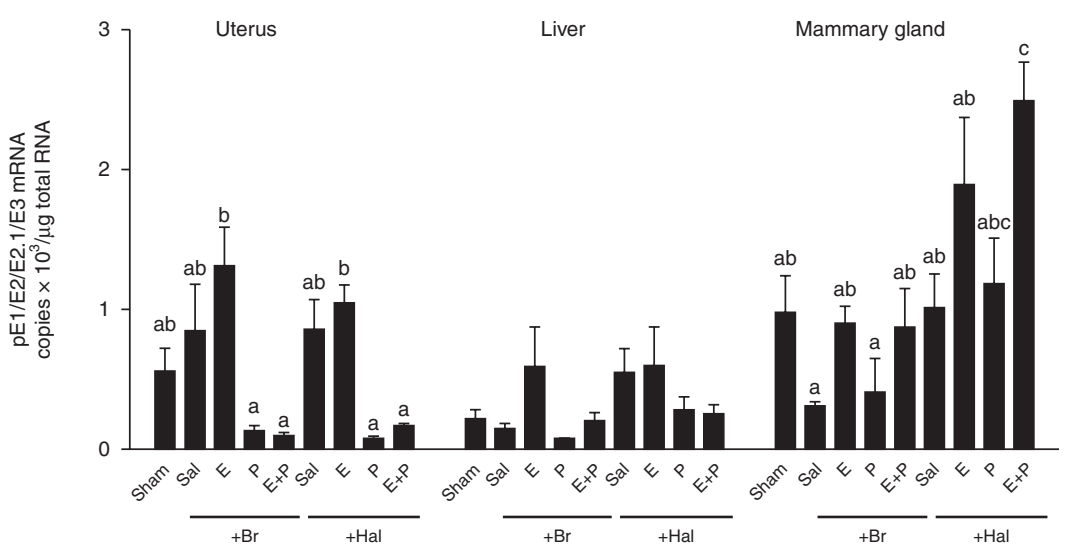

\section{Figure 4}

Expression of the different $p P R L R$ exon 1 transcripts in uterus, liver, and mammary glands of ovariectomized, bromocriptine $(\mathrm{Br})$-treated pigs administered all combinations of $E$, medroxyprogesterone 17-acetate $(P)$, and/or haloperidol (Hal). Copy number of total $p P R L R$ mRNA was measured

cells. Deleting the region -648 to -424 bp increased promoter activity by $130 \%$, suggesting the likely presence of a repressor site (Fig. 5A). Further deleting the region -424 to -170 bp reduced transcriptional activity to that by qPCR with normalization for the corresponding level of 185 rRNA. (A) Transcript pE1/3. (B) Transcript $p E 1 / 2 / 3$. (C) Transcript $p E 1 / 2 / 2.1 / 3$. Sham, sham-operated; Sal, saline treated. Data are means \pm s.E.M. $(n=4)$. $a, b, c$ Means without a common superscript differ.

of the promoterless construct. We further analyzed the region -651 to $-170 \mathrm{bp}$ to identify putative cis elements that might regulate expression from the $\mathrm{pE} 1$ promoter (Fig. 5B). The aforementioned putative repressor site was

Published by Bioscientifica Ltd. 
A

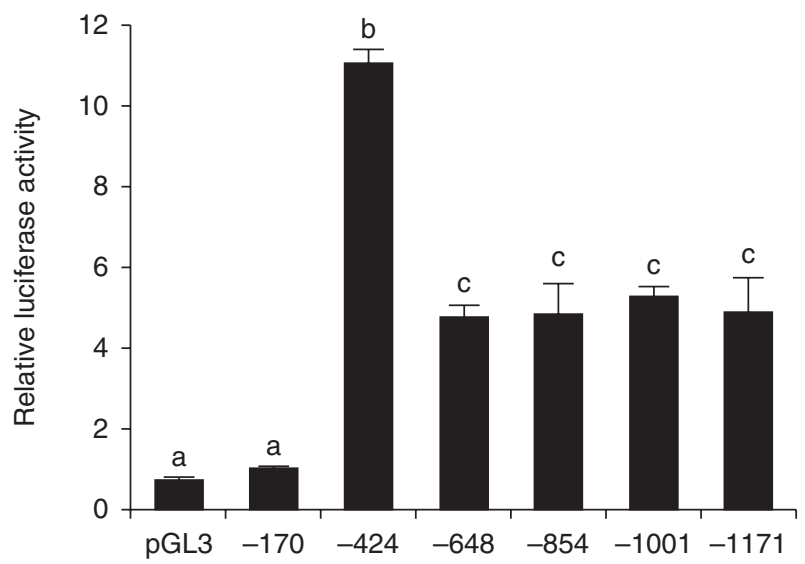

B

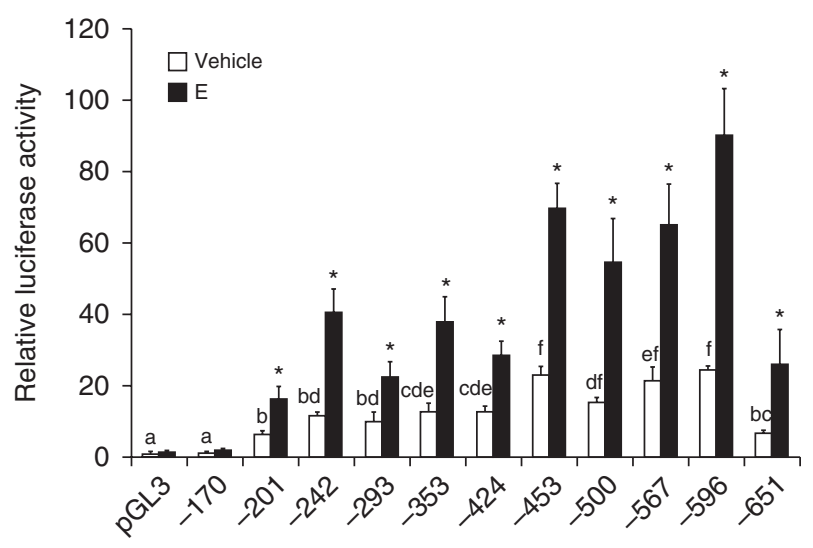

Figure 5

Promoter analysis for pE1 in MCF-7 cells transiently transfected with plasmids containing varying lengths of the $\mathrm{pE} 1$ promoter upstream of a luciferase reporter. Luciferase activity in cells transfected with pGL3-Basic that contained $170 \mathrm{bp}$ of the promoter was set to 1. (A) Cells were transfected in complete growth medium and harvested $24 \mathrm{~h}$ later. Data are means \pm s.E.M. ( $n=3$ independent experiments). (B) Deletion constructs were transfected into cells and then treated for $48 \mathrm{~h}$ with $1 \mathrm{nM} \beta$-estradiol (E) or vehicle in hormone-deficient media. Data are means \pm s.E.M. $(n=3-4$; four independent experiments). A significant difference between the response to vehicle and $E$ is indicated by *. ${ }^{a}, b, c, d, e, f$ Means without a common superscript differ $(P<0.05)$.

localized between -648 and -596 bp while a putative activation site was identified between -453 and $-424 \mathrm{bp}$. Using TESS and Alibaba, we also predicted transcription factor binding sites in this region. Candidate binding sites for pituitary-1 (Pit-1) and E26 transformation-specific (ETS) family members were identified at -629 to -624 and -645 to -640 respectively (Fig. 1C). Furthermore, CCAAT/enhancer binding protein (C/EBP) and specificity protein 1 (Sp1) binding sites that were previously shown to regulate PRLR expression in humans, rats, and mice are partially conserved in pE1 at -151 to -141 and at -139 to -131 . The smallest pE1 promoter fragment $(-170)$, which contains both the C/EBP and Sp1 binding sites, failed to promote transcription in our analyses. The downstream sequence element $(-77$ to -68$)$ that is required for $\mathrm{E} 1_{3}$ basal activity in rats (Hu et al. 1998) is partially conserved in the $\mathrm{pE} 1$ promoter but is also located in the region of the promoter that was inactive in MCF-7 cells.

Given our finding that pE1 expression in the mammary glands is E-regulated, we examined whether, and then how, E activated the pE1 promoter in MCF-7 cells. Transcription from the pE1 promoter was E-inducible for all promoter fragments that contained more than the first 170 nucleotides. ERs bind with highest affinity to palindromic estrogen response elements (EREs), although many EREs contain weaker binding sequences and some only consist of half-palindromic sites (Bourdeau et al. 2004). We identified putative ERE half-sites in the pE1 promoter at -549 to $-545,-583$ to -579 , and -592 to -588 , but none between -170 and -549 . Given that the magnitude of E-activation from the -242 fragment was higher than from the -201 fragment, we examined the -170 to -242 region for putative transcription factor binding sites. We identified a putative TFAP2A binding site between -166 and -174 (consensus G/C C C N N A/C/G G/A G G/C/T; McPherson \& Weigel 1999) and an E-box sequence ( $5^{\prime}$-CANNTG-3') from -232 to -227 . We next generated two constructs that contained either a mutated TFAP2A site in the -201 promoter or a mutated E-box in the -242 promoter. Estrogen-induced activation of the -201 promoter was ablated when the TFAP2A site was mutated (Fig. 6A), while E-activation of the -242 promoter was ablated by mutation of the E-box (Fig. 6B). The basal transcription levels were also reduced by mutating both the TFAP2A site (Fig. 6A) and the E-box (Fig. 6B). Given that the E-box and TFAP2A sites are not classical EREs, we used the ESR antagonist ICI 182780 and confirmed that the ESR is involved in the E-induced activation of these -201 and -242 bp pE1 promoter fragments (Fig. 7).

\section{Discussion}

We find that the pE1 is structurally and functionally similar to the $\mathrm{hE} 1_{3}, \mathrm{rE} 1_{3}$, and $\mathrm{mE} 1_{3}$ with regard to sequence homology, conserved cis-regulatory elements, and level of expression across tissues. These first exons in other species are regarded as the principal first exon for the PRLR gene. Furthermore, we identified that exon 2 is a variably spliced

Published by Bioscientifica Ltd. 

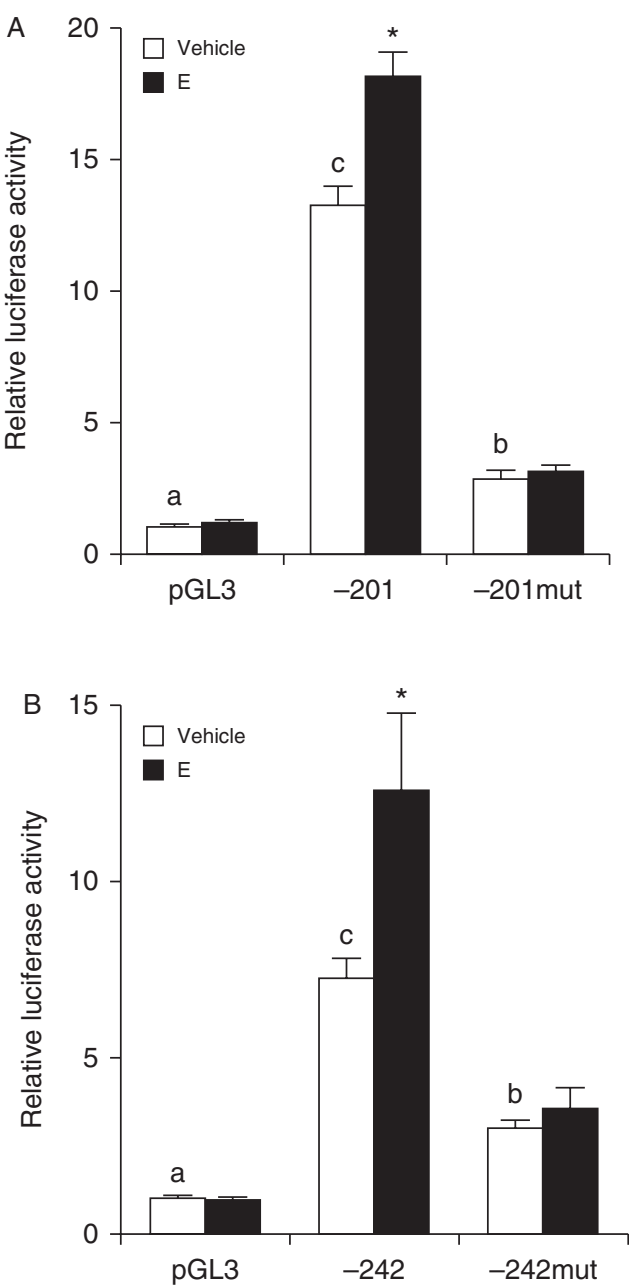

Figure 6

Analysis of transcription factor mutants for the $\mathrm{pE} 1$ promoter in MCF-7 cells transiently transfected with plasmids containing the promoter upstream of a luciferase reporter. Luciferase activity in cells transfected with pGL3-Basic and not stimulated by $\beta$-estradiol (E) was set to 1. Cells in hormonedeficient media were treated for $48 \mathrm{~h}$ with either $1 \mathrm{nM}$ E or vehicle. (A) The $201 \mathrm{bp}$ promoter was mutated at the TFAP2A binding site $(-201 \mathrm{mut})$. Data are means \pm s.E.M. $(n=3)$ from three independent experiments. (B) The 242 bp promoter was mutated at the E-box sequence $(-242 m u t)$. Data are means \pm s.E.M. $(n=3)$ from three independent experiments. A significant difference between the response to vehicle and $\mathrm{E}$ is indicated by *. ${ }^{a, b}, c$ Means without a common superscript differ $(P<0.05)$.

constituent of transcripts arising from pE1. Splicing of exons $1-3$, while omitting exon 2 , has also been reported for both the rPRLR (Hu et al. 1996) and the hPRLR (Hu et al. 1999). To our knowledge, the existence of an exon 2.1 has not been reported in any other species, although a $70 \%$ homologous sequence is present within the intron between E2 and E3 in the hPRLR gene. Alternative splicing of exon 2 and/or 2.1 would further diversify the PRLR $5^{\prime}$ UTR by deleting regulatory cis elements. This could affect PRLR mRNA stability or the rate of protein translation.
Among the various tissues we examined, expression of pE1 was most abundant in PRL-sensitive tissues and increased during gestation, similar to the expression profile for the pPRLR-LF (Trott et al. 2009). Previous analysis of the hormonal regulation of E1 transcription in vivo have been limited to select tissues such as the liver, pituitary gland and in a subset of brain regions from rats and mice or in murine and human mammary epithelial cell lines in vitro (Pi et al. 2003, Tanaka et al. 2005, Dong et al. 2006, Kobayashi et al. 2007, Nogami et al. 2007, Goldhar et al. 2011, Tabata et al. 2012). The induction of pE1 expression by $E$ and its repression by $P$ in the uterus of pigs aligns with the effect of these hormones on PPRLR-LF mRNA expression. Alternating concentrations of serum hormones during gestation may account for the changes in pE1 expression during this period (Eldridge-White et al. 1989). Here, we show that E increases pE1 mRNA expression in the mammary glands of pigs, consistent with our previous finding that $\mathrm{E}$ specifically induces pPRLR-LF expression in the mammary epithelium. It is noteworthy that the E-induction of pE1 expression here was much higher than that for pPRLR-LF (Trott et al. 2009). These results also align with our findings in breast cancer cells herein and similar reports by others (Dong et al. 2006). Investigations into the effect of progestins on $\mathrm{E} 1$ expression have been limited to mice and transiently transfected T47D

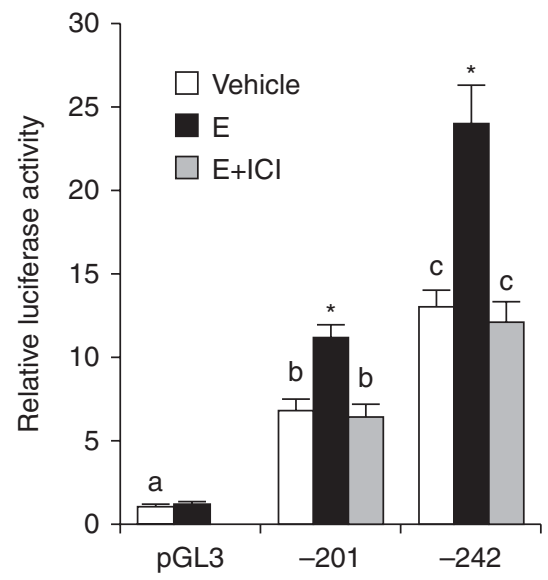

Figure 7

The $\beta$-estradiol (E) receptor antagonist ICI 182780 (ICI) inhibits E-induced activation of the $\mathrm{pE} 1$ promoter in MCF-7 cells transiently transfected with plasmids containing the promoter upstream of a luciferase reporter. Luciferase activity in cells transfected with pGL3-Basic and not stimulated by $\mathrm{E}$ was set to 1 . Cells were pre-treated for $24 \mathrm{~h}$ with $100 \mathrm{nM} \mathrm{ICl}$ or vehicle in hormone-deficient media followed by $48 \mathrm{~h}$ treatment with vehicle, $1 \mathrm{nM} \mathrm{E}$, or $\mathrm{E}+\mathrm{ICI}$. Data are means \pm s.E.M. $(n=3)$ from three independent experiments. A significant difference between the response to vehicle and $\mathrm{E}$ is indicated by * ${ }^{a}, \mathrm{~b}, \mathrm{c}$ Means without a common superscript differ $(P<0.05)$.

Published by Bioscientifica Ltd. 
breast cancer cells where progesterone induced $\mathrm{mE} 1_{3}$ transcription (Goldhar et al. 2011). Expression of pE1 in the liver is far less sensitive to hormonal regulation compared with the uterus or the mammary glands. This finding is similar to the complete lack of hormonal regulation for pPRLR-LF mRNA expression in the liver (Trott et al. 2009) and the finding that neither gonadectomy nor sex steroid hormone treatment affected $\mathrm{E} 1_{3}$ expression in the liver of rats (Tanaka et al. 2005). Others have suggested that $\mathrm{E}$ regulates $\mathrm{rE} 1_{3}$ expression in some regions of the brain such as the hypothalamus and the choroid plexus, although discrepancies exist regarding the existence and the direction of this effect ( $\mathrm{Pi}$ et al. 2003, Kobayashi et al. 2007, Nogami et al. 2007, Tabata et al. 2012). This differential hormone responsiveness may reflect a varied presence of tissue-specific transcription factors across different stages of development.

While C/EBP and SP1 sites are critical for E-induced hPRLR expression (Hu et al. 2002, Dong et al. 2006), our results indicate that the proximal C/EBP and Sp1 binding sites located between -151 and -131 are not involved in either the basal promoter activity for pE1 or its responsiveness to $\mathrm{E}$. We find that the sequence between -648 and -170 of the pE1 promoter is the primary regulator of transcription and that two proximal non-ERE but E-sensitive sites, an E-box and an TFAP2A site, contribute to ER-induced transcription directed by the $\mathrm{pE} 1$ promoter. Both also contribute to basal transcription. Dong et al. (2006) also failed to identify functional EREs in the homologous $\mathrm{hE} 1_{3}$ and proposed that transcription resulted from ligand-bound ER recruited to C/EBP $\beta$ and Sp1 response elements in the proximal part of the promoter while forming complexes with additional coactivators. We suggest two ways in which E-activation of the ER might activate the E-box to induce transcription from the pE1 promoter. First, E may directly activate upstream stimulator factors (USFs) to bind the E-box or it may activate the ESR to complex with USFs at the E-box. USF-1 binds an imperfect E-box through a complex involving USF1, ESR1, and SP1 proteins that is absolutely required for transcription from the ESR1 promoter (deGraffenried et al. 2004). Secondly, the ESR can directly activate USFs to bind an E-box in the cathepsin D promoter (Xing \& Archer 1998). Meanwhile, it is less clear how E-activation of the ER acts on the putative TFAP2A site to induce pE1 promoter activity. Others showed that TFAP2A is a major regulator of E-signaling in MCF-7 cells (Woodfield et al. 2007) and in ESR-positive breast cancer cells where it regulates transcription of the ER promoter upstream of the P1 cap site (deConinck et al. 1995). However, our discovery that a putative TFAP2A site in the porcine PRLR promoter is required for ESR-induced transcription is the first report of E-activation of a putative TFAP2A site.

The region between -648 and -596 bp of the pE1 promoter includes a candidate repressor region that contains putative binding sites for Pit- 1 and ETS. Pit- 1 is primarily expressed in the pituitary but has also been detected in the extrapituitary tissues such as placenta, lymphoid, and hematopoietic tissues, as well as in the normal and tumorous breast, and in MCF-7 cells. This factor is responsible for the transcriptional regulation of GH, PRL, and TSH expression (Holloway et al. 1995, Gil-Puig et al. 2005). ETS factors act as transcriptional repressors and/or activators and can be either ubiquitous or tissue specific (Sharrocks 2001, Wei et al. 2010).

In summary, we have identified species-specific differences in the $P R L R$ E1 promoter that may underlie the functional diversity of PRL across species. The complex multilevel transcriptional control of the PRLR could be crucial to the many biological functions of PRL.

\section{Declaration of interest}

The authors declare that there is no conflict of interest that could be perceived as prejudicing the impartiality of the research reported.

\section{Funding}

This project was supported by National Research Initiative Competitive grant no. 2008-35206-18895 from the USDA National Institute for Food and Agriculture.

\section{Acknowledgements}

The authors thank Kent Parker and interns from the UC Davis Swine Research and Teaching Facility for animal care and Caleb Sehnert from the UC Davis Meat Lab for assistance with tissue collection.

\section{References}

Bole-Feysot C, Goffin V, Edery M, Binart N \& Kelly PA 1998 Prolactin (PRL) and its receptor: actions, signal transduction pathways and phenotypes observed in PRL receptor knockout mice. Endocrine Reviews 19 225-268. (doi:10.1210/er.19.3.225)

Bourdeau V, Deschenes J, Metivier R, Nagai Y, Nguyen D, Bretschneider N, Gannon F, White JH \& Mader S 2004 Genome-wide identification of high-affinity estrogen response elements in human and mouse. Molecular Endocrinology 18 1411-1427. (doi:10.1210/me.2003-0441) deConinck EC, McPherson LA \& Weigel RJ 1995 Transcriptional regulation of estrogen receptor in breast carcinomas. Molecular and Cellular Biology 15 2191-2196.

deGraffenried LA, Hopp TA, Valente AJ, Clark RA \& Fuqua SA 2004 Regulation of the estrogen receptor $\alpha$ minimal promoter by Sp1, USF-1 and ER $\alpha$. Breast Cancer Research and Treatment 85 111-120. (doi:10.1023/B:BREA.0000025398.93829.78) http://jme.endocrinology-journals.org DOI: 10.1530/JME-12-0234
(C) 2013 Society for Endocrinology Printed in Great Britain
Published by Bioscientifica Ltd 
Dong J, Tsai-Morris CH \& Dufau ML 2006 A novel estradiol/estrogen receptor $\alpha$-dependent transcriptional mechanism controls expression of the human prolactin receptor. Journal of Biological Chemistry 281 18825-18836. (doi:10.1074/jbc.M512826200)

Eldridge-White R, Easter RA, Heaton DM, O'Day MB, Petersen GC, Shanks RD, Tarbell MK \& Sherwood OD 1989 Hormonal control of the cervix in pregnant gilts. I. Changes in the physical properties of the cervix correlate temporally with elevated serum levels of estrogen and relaxin. Endocrinology 125 2996-3003. (doi:10.1210/endo-125-6-2996)

Freking BA, Leymaster KA, Vallet JL \& Christenson RK 2007 Number of fetuses and conceptus growth throughout gestation in lines of pigs selected for ovulation rate or uterine capacity. Journal of Animal Science 85 2093-2103. (doi:10.2527/jas.2006-766)

Gill S, Peston D, Vonderhaar BK \& Shousha S 2001 Expression of prolactin receptors in normal, benign, and malignant breast tissue: an immunohistological study. Journal of Clinical Pathology 54 956-960. (doi:10.1136/jcp.54.12.956)

Gil-Puig C, Seoane S, Blanco M, Macia M, Garcia-Caballero T, Segura C \& Perez-Fernandez R 2005 Pit-1 is expressed in normal and tumorous human breast and regulates GH secretion and cell proliferation. European Journal of Endocrinology 153 335-344. (doi:10.1530/ eje.1.01962)

Goldhar AS, Duan R, Ginsburg E \& Vonderhaar BK 2011 Progesterone induces expression of the prolactin receptor gene through cooperative action of Sp1 and C/EBP. Molecular and Cellular Endocrinology 335 148-157. (doi:10.1016/j.mce.2011.01.004)

Holloway JM, Szeto DP, Scully KM, Glass CK \& Rosenfeld MG 1995 Pit-1 binding to specific DNA sites as a monomer or dimer determines genespecific use of a tyrosine-dependent synergy domain. Genes and Development 9 1992-2006. (doi:10.1101/gad.9.16.1992)

Horigan KC, Trott JF, Barndollar AS, Scudder JM, Blauwiekel RM \& Hovey RC 2009 Hormone interactions confer specific proliferative and histomorphogenic responses in the porcine mammary gland. Domestic Animal Endocrinology 37 124-138. (doi:10.1016/ j.domaniend.2009.04.002)

Hovey RC, Trott JF, Ginsburg E, Goldhar A, Sasaki MM, Fountain SJ, Sundararajan K \& Vonderhaar BK 2001 Transcriptional and spatiotemporal regulation of prolactin receptor mRNA and cooperativity with progesterone receptor function during ductal branch growth in the mammary gland. Developmental Dynamics 222 192-205. (doi:10.1002/ dvdy.1179)

Howell SJ, Anderson E, Hunter T, Farnie G \& Clarke RB 2008 Prolactin receptor antagonism reduces the clonogenic capacity of breast cancer cells and potentiates doxorubicin and paclitaxel cytotoxicity. Breast Cancer Research 10 R68. (doi:10.1186/bcr2129)

Hu Z, Zhuang L \& Dufau ML 1996 Multiple and tissue-specific promoter control of gonadal and non-gonadal prolactin receptor gene expression. Journal of Biological Chemistry 271 10242-10246. (doi:10.1074/jbc.271.17.10242)

Hu Z, Zhuang L, Guan X, Meng J \& Dufau ML 1997 Steroidogenic factor-1 is an essential transcriptional activator for gonad-specific expression of promoter I of the rat prolactin receptor gene. Journal of Biological Chemistry 272 14263-14271. (doi:10.1074/jbc.272.22.14263)

Hu ZZ, Zhuang L, Meng J \& Dufau ML 1998 Transcriptional regulation of the generic promoter III of the rat prolactin receptor gene by C/EBP $\beta$ and Sp1. Journal of Biological Chemistry 273 26225-26235. (doi:10.1074/ jbc.273.40.26225)

Hu ZZ, Zhuang L, Meng J, Leondires M \& Dufau ML 1999 The human prolactin receptor gene structure and alternative promoter utilization: the generic promoter hPIII and a novel human promoter $\mathrm{hP}(\mathrm{N})$. Journal of Clinical Endocrinology and Metabolism 84 1153-1156. (doi:10.1210/jc.84.3.1153)

Hu ZZ, Zhuang L, Meng J, Tsai-Morris CH \& Dufau ML 2002 Complex $5^{\prime}$ genomic structure of the human prolactin receptor: multiple alternative exons 1 and promoter utilization. Endocrinology 143 2139-2142. (doi:10.1210/en.143.6.2139)
Jahn GA, Edery M, Belair L, Kelly PA \& Djiane J 1991 Prolactin receptor gene expression in rat mammary gland and liver during pregnancy and lactation. Endocrinology 128 2976-2984. (doi:10.1210/ endo-128-6-2976)

Kobayashi M, Suzuki M, Saito TR \& Tanaka M 2007 Developmental changes in the expression levels of alternative first exons of prolactin receptor gene in rat brain. Endocrine Research 32 143-151. (doi:10.1080/ 07435800701764022)

Kuzmuk KN \& Schook LB 2011 Pigs as a model for biomedical sciences. In The Genetics of the Pig, edn 2, pp 426-444. Eds MF Rothschild \& A Ruvinsky. Wallingford: CAB International. (doi:10.1079/ 9781845937560.0014)

McPherson LA \& Weigel RJ 1999 AP2 $\alpha$ and AP2 $\gamma$ : a comparison of binding site specificity and trans-activation of the estrogen receptor promoter and single site promoter constructs. Nucleic Acids Research $\mathbf{2 7}$ 4040-4049. (doi:10.1093/nar/27.20.4040)

Moldrup A, Ormandy C, Nagano M, Murthy K, Banville D, Tronche F \& Kelly PA 1996 Differential promoter usage in prolactin receptor gene expression: hepatocyte nuclear factor 4 binds to and activates the promoter preferentially active in the liver. Molecular Endocrinology 10 661-671. (doi:10.1210/me.10.6.661)

Nogami H, Hoshino R, Ogasawara K, Miyamoto S \& Hisano S 2007 Regionspecific expression and hormonal regulation of the first exon variants of rat prolactin receptor mRNA in rat brain and anterior pituitary gland. Journal of Neuroendocrinology 19 583-593. (doi:10.1111/j.1365-2826. 2007.01565.x)

Ormandy CJ, Binart N, Helloco C \& Kelly PA 1998 Mouse prolactin receptor gene: genomic organization reveals alternative promoter usage and generation of isoforms via alternative 3 '-exon splicing. DNA and Cell Biology 17 761-770. (doi:10.1089/dna.1998.17.761)

Peirce SK \& Chen WY 2001 Quantification of prolactin receptor mRNA in multiple human tissues and cancer cell lines by real time RT-PCR. Journal of Endocrinology 171 R1-R4. (doi:10.1677/joe.0. 171R001)

Pi X, Zhang B, Li J \& Voogt JL 2003 Promoter usage and estrogen regulation of prolactin receptor gene in the brain of the female rat. Neuroendocrinology 77 187-197. (doi:10.1159/000069510)

Sharrocks AD 2001 The ETS-domain transcription factor family. Nature Reviews. Molecular Cell Biology 2 827-837. (doi:10.1038/35099076)

Tabata H, Kobayashi M, Ikeda JH, Nakao N, Saito TR \& Tanaka M 2012 Characterization of multiple first exons in murine prolactin receptor gene and the effect of prolactin on their expression in the choroid plexus. Journal of Molecular Endocrinology 48 169-176. (doi:10.1530/ JME-11-0122)

Tanaka M, Hayashida Y, Iguchi T, Nakao N, Suzuki M, Nakai N \& Nakashima K 2002 Identification of a novel first exon of prolactin receptor gene expressed in the rat brain. Endocrinology 143 2080-2084. (doi:10.1210/en.143.6.2080)

Tanaka M, Suzuki M, Kawana T, Segawa M, Yoshikawa M, Mori M, Kobayashi M, Nakai N \& Saito TR 2005 Differential effects of sex steroid hormones on the expression of multiple first exons including a novel first exon of prolactin receptor gene in the rat liver. Journal of Molecular Endocrinology 34 667-673. (doi:10.1677/jme.1.01702)

Trott JF, Farley NR, Taatjes DJ \& Hovey RC 2007 Cloning and functional characterization of allelic variation in the porcine prolactin receptor. Domestic Animal Endocrinology 33 313-334. (doi:10.1016/j.domaniend. 2006.07.001)

Trott JF, Horigan KC, Gloviczki JM, Costa KM, Freking BA, Farmer C, Hayashi K, Spencer T, Morabito JE \& Hovey RC 2009 Tissue-specific regulation of porcine prolactin receptor expression by estrogen, progesterone, and prolactin. Journal of Endocrinology 202 153-166. (doi:10.1677/JOE-08-0486)

Trott JF, Schennink A \& Hovey RC 2011 Cloning and expression of a unique short form of the porcine prolactin receptor. Journal of Molecular Endocrinology 46 51-62. (doi:10.1677/JME-10-0101) 
Trott JF, Schennink A, Petrie WK, Manjarin R, Vanklompenberg MK \& Hovey RC 2012 Prolactin: the multi-faceted potentiator of mammary growth and function. Journal of Animal Science 90 1674-1686. (doi:10.2527/jas.2011-4682)

Wei GH, Badis G, Berger MF, Kivioja T, Palin K, Enge M, Bonke M, Jolma A, Varjosalo M, Gehrke AR et al. 2010 Genome-wide analysis of ETS-family DNA-binding in vitro and in vivo. EMBO Journal 29 2147-2160. (doi:10.1038/emboj.2010.106)
Woodfield GW, Horan AD, Chen Y \& Weigel RJ 2007 TFAP2C controls hormone response in breast cancer cells through multiple pathways of estrogen signaling. Cancer Research 67 8439-8443. (doi:10.1158/ 0008-5472.CAN-07-2293)

Xing W \& Archer TK 1998 Upstream stimulatory factors mediate estrogen receptor activation of the cathepsin D promoter. Molecular Endocrinology 12 1310-1321. (doi:10.1210/me. 12.9.1310)

Received in final form 29 March 2013

Accepted 10 April 2013

Accepted Preprint published online 10 April 2013
Published by Bioscientifica Ltd. 